\title{
WASTES II Model Storage Requirements Benchmark Testing
}

M. R. Shay

R. C. Walling

M. K. Altenhofen

September 1986

Prepared for the U.S. Department of Energy under Contract DE-AC06-76RLO 1830

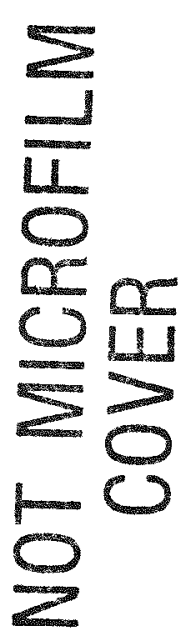

Pacific Northwest Laboratory

Operated for the U.S. Department of Energy by Battelle Memorial Institute 


\title{
DISCLAIMER
}

This report was prepared as an account of work sponsored by an agency of the United States Government. Neither the United States Government nor any agency thereof, nor any of their employees, makes any warranty, express or implied, or assumes any legal liability or responsibility for the accuracy, completeness, or usefulness of any information, apparatus, product, or process disclosed, or represents that its use would not infringe privately owned rights. Reference herein to any specific commercial product, process, or service by trade name, trademark, manufacturer, or otherwise, does not necessarily constitute or imply its endorsement, recommendation, or favoring by the United States Government or any agency thereol. The views and opinions of authors expressed herein do not necessarily state or reflect those of the United States Government or any agency thereof.

\author{
PACIFIC NORTHWEST LABORATORY \\ operated by \\ BATTELLE \\ for the \\ UNITED STATES DEPARTMENT OF ENERGY \\ under Contract DE-AC06-76RLO 1830
}

\begin{tabular}{|c|c|}
\hline \multirow{4}{*}{\multicolumn{2}{|c|}{$\begin{array}{c}\text { Printed in the United States of America } \\
\text { Available from } \\
\text { National Technical Information Service } \\
\text { United States Department of Commerce } \\
5285 \text { Porf Royal Road } \\
\text { Springfield, Virginia } 22161\end{array}$}} \\
\hline & \\
\hline & \\
\hline & \\
\hline \multicolumn{2}{|c|}{$\begin{array}{l}\text { NTIS Price Codes } \\
\text { Microfiche A01 }\end{array}$} \\
\hline \multicolumn{2}{|c|}{ Printed Copy } \\
\hline Pages & $\begin{array}{l}\text { Price } \\
\text { Codes }\end{array}$ \\
\hline $001-025$ & $A 02$ \\
\hline $026-050$ & $\mathrm{~A} 03$ \\
\hline $051-075$ & $\mathrm{AO} 4$ \\
\hline $076-100$ & A05 \\
\hline $101-125$ & A06 \\
\hline $126-150$ & $\mathrm{~A} 07$ \\
\hline $151-175$ & A08 \\
\hline $176-200$ & $A 09$ \\
\hline $201-225$ & A070 \\
\hline $226-250$ & A011 \\
\hline $251-275$ & A012 \\
\hline $276-300$ & $\mathrm{~A} 013$ \\
\hline
\end{tabular}




\section{DISCLAIMER}

This report was prepared as an account of work sponsored by an agency of the United States Government. Neither the United States Government nor any agency Thereof, nor any of their employees, makes any warranty, express or implied, or assumes any legal liability or responsibility for the accuracy, completeness, or usefulness of any information, apparatus, product, or process disclosed, or represents that its use would not infringe privately owned rights. Reference herein to any specific commercial product, process, or service by trade name, trademark, manufacturer, or otherwise does not necessarily constitute or imply its endorsement, recommendation, or favoring by the United States Government or any agency thereof. The views and opinions of authors expressed herein do not necessarily state or reflect those of the United States Government or any agency thereof. 


\section{DISCLAIMER}

Portions of this document may be illegible in electronic image products. Images are produced from the best available original document. 
PNL- -5959

DE86 015986

\title{
WASTES II Model Storage Requirements Benchmark Testing
}

\author{
M. R. Shay \\ R. C. Walling \\ M. K. Altenhofen
}

September 1986

Prepared for the U.S. Department of Energy under Contract DE-AC06-76RLO 1830

Pacific Northwest Laboratory Operated for the U.S. Department of Energy by Battelle Memorial Institute 


\title{
DISCLAIMER
}

This report was prepared as an account of work sponsored by an agency of the United States Covernment. Neither the United States Government nor any agency thereof, nor any of their employees, makes any warranty, express or implied, or assumes any legal liability or responsibility for the accuracy, completeness, or usefulness of any information, apparatus, product, or process disclosed, or represents that its use would not infringe privately owned rights. Reference herein to any specific commercial product, process, or service by trade name, trademark, manufacturer, or otherwise, does not necessarily constitute or imply its endorsement, recommendation, or favoring by the United States Government or any agency thereof. The views and opinions of authors expressed herein do not necessarily state or reflect those of the United States Government or any agency thereof.

\author{
PACIFIC NORTHWEST LABORATORY \\ operated by \\ BATTELLE \\ for the \\ UNITED STATES DEPARTMENT OF ENERGY \\ under Contract DE-AC06-76RLO 1830
}

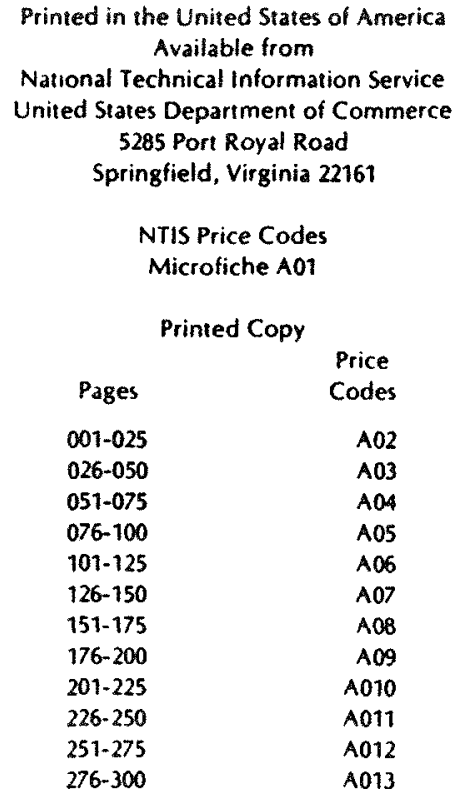


WASTES II MODEL STORAGE REQUIREMENTS

BENCHMARK TESTING

M. R. Shay

R. C. Walling

M. K. Altenhofen

September 1986

Prepared for

the U.S. Department of Energy

under Contract DE-AC06-76RLO 1830

Pacific Northwest Laboratory

Richland, Washington 99352 


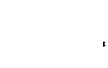


SUMMARY

The Pacific Northwest Laboratory (PNL) has conducted a study to benchmark results obtained from using the Waste System Transportation and Economic Simulation - Version II (WASTES II) model (Shay and Buxbaum 1986) against information published in the Spent Fuel Storage Requirements report (DOE 1984). The WASTES model was developed by PNL for use in evaluating the spentfuel storage and transportation requirements and costs for the U. S. Department of Energy (DOE). The Spent Fuel Storage Requirements report is issued annually by the DOE and provides both historical/projected spent fuel inventory data and storage requirements data based on information supplied directly from utilities. The objective of this study is to compare the total inventory and storage requirements documented in the Spent Fuel Storage Requirements report with similar data that results from use of the WASTES model.

Three differences have been identified as a result of benchmark testing. Two minor differences are present in the total inventory projected and the equivalent metric tons of uranium (MTU) of spent fuel requiring storage. These differences result from the way reinserted spent fuel is handled and the methods used to calculate mass equivalents. A third difference is found in the storage requirements for the case that uses intra-utility transshipment. This discrepancy is due to the Oyster Creek reactor, which is shown to not require additional storage in the Spent Fuel Storage Requirements report, even though there is no destination reactor of the same type within its utility. The discrepancy was corrected soon after the 1984 Spent Fuel Storage Requirements report was issued and does not appear in more recent documents (DOE 1985).

The results of benchmark testing demonstrate that the WASTES II model can be used to predict the requirements for additional at-reactor storage capacity. In addition, these results provide assurances that the WASTES II model produces reliable estimates of the spent-fuel logistics resulting from alternative spent-fuel management systems. It is recommended that the WASTES II model be benchmarked against other models of comparable design when they are available. 
CONTENTS

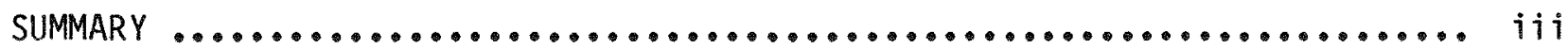

1.0 INTRODUCTION $\ldots \ldots \ldots \ldots \ldots \ldots \ldots \ldots \ldots \ldots \ldots \ldots \ldots \ldots \ldots \ldots \ldots \ldots \ldots \ldots \ldots \ldots \ldots \ldots \ldots$

2.0 WASTES II MODEL DESCRIPTION $\ldots \ldots \ldots \ldots \ldots \ldots \ldots \ldots \ldots \ldots \ldots \ldots \ldots \ldots \ldots \ldots \ldots \ldots \ldots \ldots \ldots \ldots \ldots$

3.0 SPENT FUEL REQUIREMENTS REPORT DESCRIPTION ................. 3.1

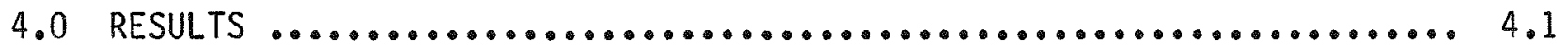

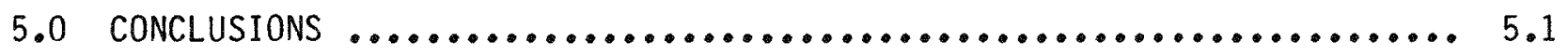

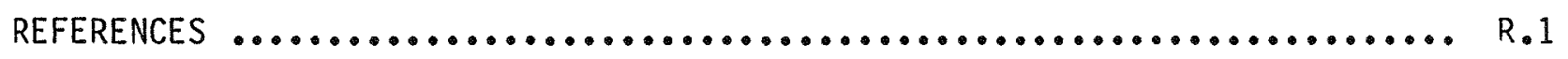

APPENDIX A - WASTES II MODEL RESULTS--ANNUAL STORAGE REQUIREMENTS ....... A.1 


\section{TABLES}

4.1 WASTES II Model Benchmark Test Result--Maximum Pool Capacity ....... 4.2

4.2 WASTES II Model Benchmark Test Results--Intra-Utility

Transshipment........................................ 4.4 


\subsection{INTRODUCTION}

The WASTES II model was developed by PNL for use in evaluating the spent fuel storage and transportation requirements and costs for the DOE. As part of mode1 development, benchmark tests were conducted to compare the data that resulted from using WASTES II with the information published in the 1984 Spent Fuel Storage Requirements report (DOE 1984). This report provides a brief description of the two independent approaches and discusses the results of the benchmark tests. The total inventories and requirements for additional atreactor storage capacity are compared for the maximum pool capacity and intrautility transshipment cases described in the Spent Fuel Storage Requirements report. 


\subsection{WASTES II MODEL DESCRIPTION}

The WASTES II model simulates a user-defined system of nuclear spent-fuel generation, transportation, storage and final disposal. The number of each type of receiving facility, their locations and capacities, and priorities for waste acceptance are all specified by the user. The simulation is initiated with input data files that contain information about reactor-site characteristic and spent-fuel discharges. The reactor-site data file provides reactor site-specific data for each reactor present in the simulation. The reactor discharge data file provides the characteristics of each batch of spent fuel discharged in the simulation. From this point, the model is controlled by a user-specified combination of source- and destination-originated transfers.

During the simulation, spent-fuel transfers occur when a reactor pool violates the full core reserve (FCR) storage margin or when the reactor is decommissioned. At these times, the source reactor checks destination facilities to see if they can accept spent fuel. If the FCR margin cannot be maintained, the simulation will attempt to transship to another reactor pool, when transshipment is allowed. For the transshipment case, material will be transshipped to the storage pool with the largest capacity within the utility network. If transshipment is not allowed or if the transshipment is refused, the reactor will place excess material in dry storage. A dry storage facility is assumed to exist for each reactor and is allowed to grow as necessary to contain spent fuel that cannot be shipped to any other facility. In this way, the dry-storage inventories represent the requirements for additional at-reactor storage capacity. 


\subsection{SPENT FUEL STORAGE REQUIREMENTS REPORT DESCRIPTION}

The Spent Fuel Storage Requirements report is published annually for the DOE Commercial Spent Fuel Management (CSFM) Program. The 1984 estimates of at-reactor storage requirements are based on information supplied by nuclear utilities during $\mathrm{Cr}$ 1983. The Spent Fuel Storage Requirements report provides a basis for planning the DOE's Federal Interim Storage Program and various research and development activities within the CSFM Program. These estimates are based on the maximum at-reactor pool storage capacities of individual reactor pools, as determined by the utilities, and allowances for maintaining an FCR margin for each separate reactor. A single FCR margin is maintained for all units at multiple reactor stations sharing the same spent-fuel storage pool, or separate storage pools with interconnections for spent-fuel transfers. Two reference cases were used to develop the estimates. The first case assumes that transshipments occur only as currentiy planned by the utilities. The second case assumes that there are no constraints on transshipments of spent fuel among reactors of like type within a given utility system, thus delaying the utilities need for additional at-reactor storage capacity. Such transshipments are included in the spent-fuel management plans of several utilities. The two reference cases, therefore, define a range of potential storage requirements. 
4.0 RESULTS

Cumulative total inventory and at-reactor storage requirements are shown in Table 4.1 for the maximum pool capacity case and Table 4.2 for the intrautility transshipment case. For each case, there are minor differences in the total inventory amount for the period of time between 1983 and 1993. In addition, there are minor differences in the storage requirements expressed in terms of MTU's and a more significant difference in the storage requirements beginning in year 1992 for the case where transshipment occurs. These differences are explained below.

As shown in Table 4.1, the differences in total inventory amount are due to how reinserted spent fuel assemblies are accounted for with each approach. The Spent Fuel Storage Requirements report counts all fuel which has ever been discharged in the total inventory, including fuel which will be reinserted. Reinserted fuel is removed from inventory during the period of time that it is to be returned to the reactor, and is included again following final discharge. The WASTES II model is concerned with the logistics and costs associated with fuel which is to be stored or disposed, and the data used by WASTES only includes fuel which is permanently discharged. The inventory calculated by the WASTES model differs from that shown in the Storage Requirements report by less than 1 percent. This difference does not have a significant effect on the calculated storage requirements.

The differences in the at-reactor storage requirements expressed in MTU's are due to the different methods used to calculate equivalent mass equivalents. WASTES II bases the number of MTU's on individual spent-fuel discharge batch characteristics. WASTES II also maintains the age, exposure and heat generation rate characteristics of each spent-fuel batch. The approach used in the Spent Fuel Storage Requirements report uses the overall average assembly weight values specified for each reactor. As a result, WASTES II provides better estimates for MTU equivalents of spent fuel requiring storage. This difference is not judged to be significant since requirements are more often quoted on an assembly basis. 
TABLE 4.1. WASTES II Model Benchmark Test Results--Maximum Pool Capacity

\begin{tabular}{|c|c|c|c|c|c|c|c|c|c|}
\hline & & & VASTES $\|$ & del Results & & Resu & $\begin{array}{l}\text { from the } \\
\text { Requirem }\end{array}$ & $\begin{array}{l}\text { pent Fuel St } \\
\text { ts Report }\end{array}$ & age \\
\hline & Year & $\begin{array}{l}\text { Storage Re } \\
\text { Assemblies }\end{array}$ & $\frac{1 \text { Trement }}{\text { MTU }}$ & $\begin{array}{l}\text { Total } \\
\text { AssembIles }\end{array}$ & $\begin{array}{l}\text { ntory } \\
\text { MTU }\end{array}$ & $\begin{array}{l}\text { Storage Re } \\
\text { Assembites }\end{array}$ & $\frac{\text { Trement }}{\text { MTU }}$ & $\begin{array}{l}\text { Total Tn } \\
\text { Assemblles }\end{array}$ & $\begin{array}{l}\text { ntory } \\
\text { MTU }\end{array}$ \\
\hline & 1983 & 0 & 0.0 & 37,113 & $10,074.3$ & 0 & 0.0 & 37,271 & $10,142.0$ \\
\hline & 1984 & 0 & 0.0 & 41,781 & $11,397.8$ & 0 & 0.0 & 41,843 & $11,425.0$ \\
\hline & 1985 & 3 & 1.2 & 47,628 & $13,143.4$ & 3 & 1.0 & 47,672 & $13,163.0$ \\
\hline 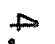 & 1986 & 69 & 27.5 & 55,049 & $15,172.3$ & 69 & 28.0 & 55,082 & $15,187.0$ \\
\hline & 1987 & 363 & 117.3 & 62,984 & $17,449.1$ & 363 & 119.0 & 63,010 & $17,461.0$ \\
\hline & 1988 & 704 & 263.0 & 72,594 & $20,178.6$ & 704 & 266.0 & 72,612 & $20,187,0$ \\
\hline & 1989 & 1,268 & 460.6 & 81,036 & $22,647.2$ & 1,268 & 459.0 & 81,053 & $22,655.0$ \\
\hline & 1990 & 2,824 & 896.9 & 90,622 & $25,377.0$ & 2,824 & 893.0 & 90,630 & $25,381.0$ \\
\hline & 1991 & 5,032 & $1,441.7$ & 100,703 & $28,199.4$ & 5,032 & $1,429.0$ & 100,707 & $28,201.0$ \\
\hline & 1992 & 6,507 & $1,880.1$ & 110,173 & $30,976.2$ & 6,507 & $1,861.0$ & 110,177 & $30,978.0$ \\
\hline & 1993 & 8,874 & $2,500.8$ & 120,368 & $33,876.8$ & 8,874 & $2,472.0$ & 120,368 & $33,877.0$ \\
\hline
\end{tabular}


As shown in Table 4.2, the difference in the storage requirements for the case with intra-utility transshipment beginning in year 1992 is due to the situation at Oyster Creek reactor. As shown in Appendix A, Oyster Creek is not affected by intra-utility transshipment because a destination reactor of the same type does not exist within its utility system. The Spent Fuel Storage Requirements report indicates that Oyster Creek reactor storage requirements are impacted by intra-utility transshipment. This discrepancy was examined and it was found that the results reported in the Spent Fuel Requirements report were in error, but had been corrected prior to this benchmark. Comparison of WASTES II model results with more recent reports (Heeb, Libby, and Holter 1985, DOE 1985) indicate full agreement. 
TABLE 4.2. WASTES II Model Benchmark Test Results--Intra-Utility Transshipment

\begin{tabular}{|c|c|c|c|c|c|c|c|c|c|}
\hline & & & ASTES 11 & del Results & & Resu & $\begin{array}{l}\text { from the } \\
\text { Requiren }\end{array}$ & $\begin{array}{l}\text { Spent Fuel S } \\
\text { its Report }\end{array}$ & Storage \\
\hline & Year & $\frac{\text { Sforage Re }}{\text { Assemblies }}$ & $\frac{\text { Trement }}{\text { MTU }}$ & $\begin{array}{l}\text { Total } \\
\text { Assemblios }\end{array}$ & $\frac{n \text { ntory }}{\text { MTU }}$ & $\begin{array}{l}\text { Storage R } \\
\text { Assemblies }\end{array}$ & $\frac{\text { Trement }}{\text { MTU }}$ & $\begin{array}{l}\text { Total } \\
\text { Assemblles }\end{array}$ & $\frac{\text { Inventory }}{s}$ \\
\hline & 1983 & 0 & 0.0 & 37,113 & $10,074.3$ & 0 & 0.0 & 37,271 & $10,142.0$ \\
\hline & 1984 & 0 & 0.0 & 41,781 & 11.397 .8 & 0 & 0.0 & 41,843 & 11.425 .0 \\
\hline & 1985 & 0 & 0.0 & 47,628 & $13,143.4$ & 0 & 0.0 & 47,672 & 13.163 .0 \\
\hline & 1986 & 0 & 0.0 & 55,049 & 15.172 .3 & 0 & 0.0 & 55,082 & 15.187 .0 \\
\hline 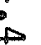 & 1987 & 132 & 24.4 & 62,984 & 17.449 .1 & 132 & 23.0 & 63,010 & $17,461.0$ \\
\hline & 1988 & 132 & 24.4 & 72,594 & $20,178.6$ & 132 & 23.0 & 72,612 & $20,187.0$ \\
\hline & 1989 & 337 & 65.6 & 81,036 & $22,647.2$ & 337 & 61.0 & 81,053 & 22.655 .0 \\
\hline & 1990 & 663 & 152.8 & 90,622 & $25,377.0$ & 663 & 147.0 & 90,630 & 25.381 .0 \\
\hline & 1991 & 1,575 & 382.0 & 100,703 & $28,199.4$ & 1.575 & 369.0 & 100,707 & $28,201.0$ \\
\hline & 1992 & 2,756 & 690.1 & 110,173 & $30,976.2$ & 2,620 & 640.0 & 110,177 & $30,978.0$ \\
\hline & 1993 & 4,045 & $1,084.6$ & 120,368 & $33,876.8$ & 3,909 & 1023.0 & 120,368 & $33,877.0$ \\
\hline
\end{tabular}




\subsection{CONCLUSIONS}

The results of benchmark testing demonstrate that the WASTES II model accurately predicts the requirements for additional at-reactor storage capacity for a no-acceptance scenario. In addition, these results provide assurances that the WASTES II model produces reliable estimates of the storage requirements resulting from alternative spent-fuel management systems. It is recommended that that WASTES II be benchmarked against other models of comparable design when they are available. 


\section{REFERENCES}

Heeb, C. M., R. A. Libby, and G. M. Holter. 1985. Reactor-Specific Spent Fuel Discharge Projections: 1984 to 2020. PNL-5396, Pacific Northwest Laboratory, Richland, Washington.

Shay, M. R. and M. E. Buxbaum. 1986. WASTES II: Waste System Transportation and Economic Simulation - Version II. Users Guide. PNL-5714, Pacific Northwest Laboratory, Richland, Washington.

U.S. Department of Energy (DOE). 1984. Spent Fuel Storage Requirements. DOE/RL-84-1, Richland Operations Office, Richland, Washington.

U.S. Department of Energy (DOE). 1985. Spent Fuel Storage Requirements. DOE/RL-85-2, Richland Operations office, Richtand, Washington. 
APPENDIX A

WASTES II MODEL RESULTS--ANNUAL STORAGE REQUIREMENTS 
TABLE A.1. WASTES II Model Results--Annual Storage Requirements--Maximum Pool Capacity Case

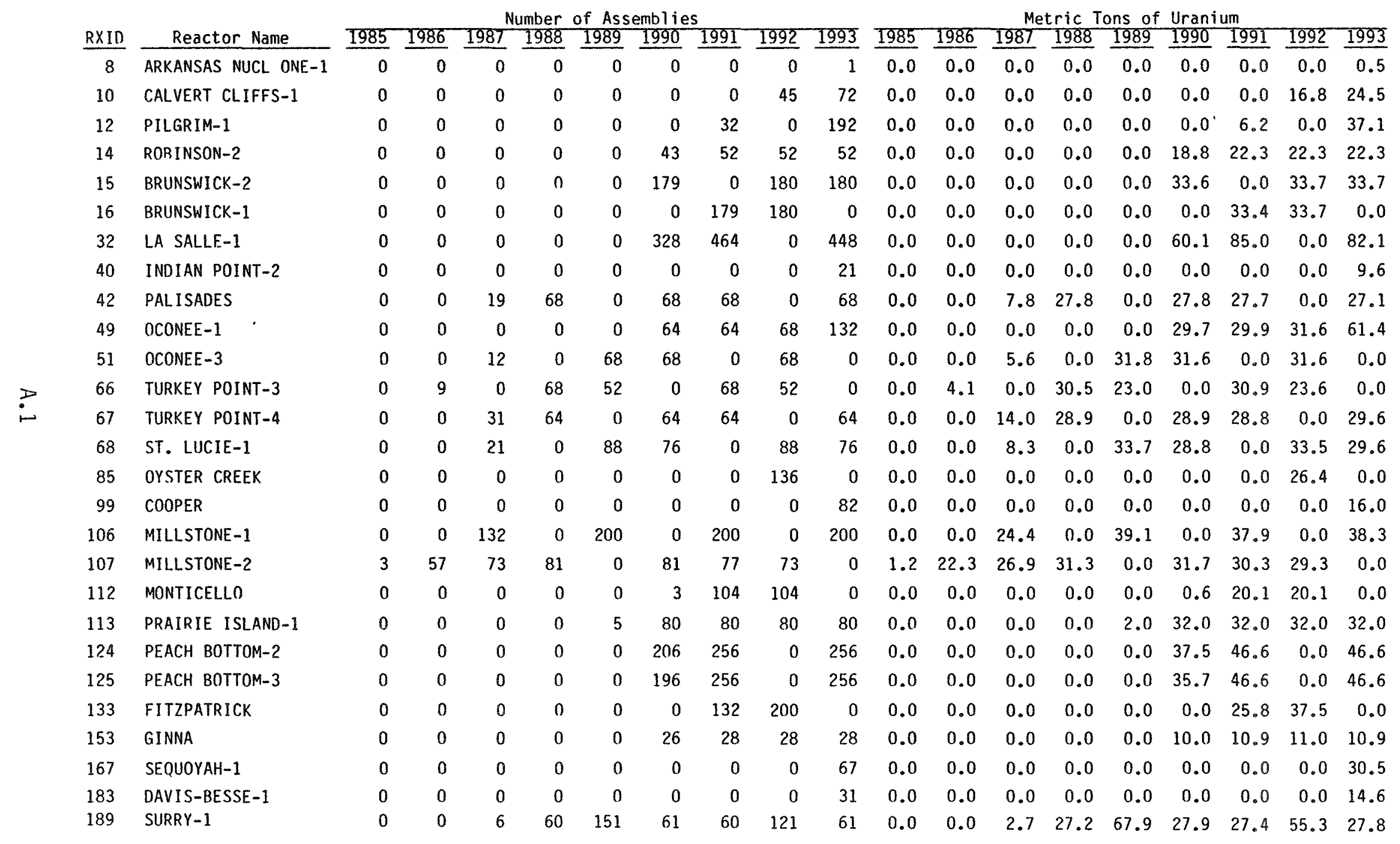


TABLE A.2. WASTES II Model Results--Annual Storage Requirements--Intra-Utility Transshipment Case

$\begin{array}{rll}\frac{\text { RXID }}{10} & & \text { Reactor Name } \\ 12 & \text { CALVERT CLIFFS-1 } \\ 15 & \text { BRUNSWICK-2 } \\ 16 & \text { BRUNSWICK-1 } \\ 40 & \text { INDIAN POINT-2 } \\ 45 & \text { LA CRNSSE } \\ 66 & \text { TURKEY POINT-3 } \\ 67 & \text { TURKEY POINT-4 } \\ 68 & \text { ST. LUCIE-1 } \\ 69 & \text { ST. LUCIE-2 } \\ 85 & \text { OYSTER CREEK } \\ 99 & \text { COOPER } \\ 106 & \text { MILLSTONE-1 } \\ 112 & \text { MONTICELLO } \\ 113 & \text { PRAIRIE ISLAND-1 } \\ 133 & \text { FITZPATRICK } \\ 153 & \text { GINNA } \\ 183 & \text { DAVIS-BESSE-1 } \\ 189 & \text { SURRY-1 } \\ 191 & \text { NORTH ANNA-1 }\end{array}$

\begin{tabular}{|c|c|c|c|c|c|c|c|c|c|c|c|c|c|}
\hline \multicolumn{7}{|c|}{ Number of Assemblies } & \multirow{2}{*}{\multicolumn{7}{|c|}{ 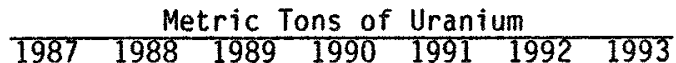 }} \\
\hline & 1988 & & 1990 & & 1992 & 1993 & 1987 & 1988 & & & & 1992 & 1993 \\
\hline 0 & 0 & c & 0 & 0 & 45 & 72 & 0.0 & 0.0 & 0.0 & 0.0 & 0.0 & 16.8 & 24.5 \\
\hline 0 & 0 & $c$ & 0 & 32 & 0 & 192 & 0.0 & 0.0 & 0.0 & 0.0 & 6.2 & 0.0 & 37.1 \\
\hline 0 & 0 & c & 178 & 0 & 180 & 180 & 0.0 & 0.0 & 0.0 & 33.4 & 0.0 & 33.7 & 33.7 \\
\hline 0 & 0 & 0 & 0 & 180 & 180 & 0 & 0.0 & 0.0 & 0.0 & 0.0 & 33.6 & 33.7 & 0.0 \\
\hline 0 & 0 & 0 & 0 & 0 & 0 & 21 & 0.0 & 0.0 & 0.0 & 0.0 & 0.0 & 0.0 & 9.6 \\
\hline 0 & 0 & 0 & 13 & 24 & 0 & 0 & 0.0 & 0.0 & 0.0 & 1.6 & 2.9 & 0.0 & 0.0 \\
\hline 0 & 0 & $n$ & 0 & 68 & 52 & 0 & 0.0 & 0.0 & 0.0 & 0.0 & 30.9 & 23.6 & 0.0 \\
\hline 0 & 0 & c & 0 & 64 & 0 & 64 & 0.0 & 0.0 & 0.0 & 0.0 & 28.8 & 0.0 & 29.6 \\
\hline 0 & 0 & 0 & 26 & 0 & 88 & 76 & 0.0 & 0.0 & 0.0 & 9.7 & 0.0 & 33.5 & 29.6 \\
\hline 0 & 0 & 0 & 0 & 0 & 88 & 76 & 0.0 & 0.0 & 0.0 & 0.0 & 0.0 & 39.8 & 33.8 \\
\hline 0 & 0 & 0 & 0 & 0 & 136 & 0 & 0.0 & 0.0 & 0.0 & 0.0 & 0.0 & 26.4 & 0.0 \\
\hline 0 & 0 & 0 & 0 & 0 & 0 & 82 & 0.0 & 0.0 & 0.0 & 0.0 & 0.0 & 0.0 & 16.0 \\
\hline 132 & 0 & 200 & 0 & 200 & 0 & 200 & 24.4 & 0.0 & 39.1 & 0.0 & 37.9 & 0.0 & 38.3 \\
\hline 0 & 0 & 0 & 3 & 104 & 104 & 0 & 0.0 & 0.0 & 0.0 & 0.6 & 20.1 & 20.1 & 0.0 \\
\hline 0 & 0 & 5 & 80 & 80 & 80 & 80 & 0.0 & 0.0 & 2.0 & 32.0 & 32.0 & 32.0 & 32.0 \\
\hline 0 & 0 & 0 & 0 & 132 & 200 & 0 & 0.0 & 0.0 & 0.0 & 0.0 & 25.8 & 37.5 & 0.0 \\
\hline 0 & 0 & 0 & 26 & 28 & 28 & 28 & 0.0 & 0.0 & 0.0 & 10.0 & 10.9 & 11.0 & 10.9 \\
\hline 0 & 0 & 0 & 0 & 0 & 0 & 31 & 0.0 & 0.0 & 0.0 & 0.0 & 0.0 & 0.0 & 14.6 \\
\hline 0 & 0 & 0 & 0 & 0 & 0 & 61 & 0.0 & 0.0 & 0.0 & 0.0 & 0.0 & 0.0 & 27.9 \\
\hline 0 & 0 & 0 & 0 & 0 & 0 & 126 & 0.0 & 0.0 & 0.0 & 0.0 & 0.0 & 0.0 & 56.9 \\
\hline
\end{tabular}




\section{DISTRIBUTION}

No. of

Copies

OFFSITE

J. H. Carlson

U.S. Department of Energy

1000 Independence Avenue, SW Washington, DC 20585

C. W. Conner

U.S. Department of Energy

1000 Independence Avenue, SW

Washington, DC 20585

K. A. Klein

U.S. Department of Energy

1000 Independence Avenue, SE Washington, DC 20585

L. Marks

U.S. Department of Energy

1000 Independence Avenue, SE Washington, DC 20585

M. L. Payton

U.S. Department of Energy

1000 Independence Avenue, SE

Washington, DC 20585

E. L. Wilmot

U.S. Department of Energy

1000 Independence Avenue, SE

Washington, DC 20585

Cindy Boggs-Mayes

Chicago Operations Office

U.S. Department of Energy

9800 S. Cass Avenue

Argonne, IL 60439

P. J. Gross

Oak Ridge Operations Office

U.S. Department of Energy

Oak Ridge, TN 37830
No. of

Copies

M. A. Heiskell

Oak Ridge Operations Office

U.S. Department of Energy

Oak Ridge, TN 37830

L. Schappert

Oak Ridge National Laboratory

P.0. Box X

Oak Ridge, TN 37830

J. W. Cashwel]

Sandia National Laboratories

P.0. Box 5800

Albuquerque, NM 87185

R. Luna

Sandia National Laboratories

P.0. Box 5800

Albuquerque, NM 87185

S. Gupta

Battelle-Columbus Laboratories

OSTP Department

505 King Avenue

Columbus, $\mathrm{OH} 43201$

R. Peterson

Battelle-Columbus Laboratories

OSTP Department

505 King Avenue

Columbus, $\mathrm{OH} 43201$

30 DOE Technical Information

Center

ONSITE

5 DOE Richland Operations Office

M. Dayani

R. B. Goranson

R. D. Izatt

D. C. Langstaff

J. J. Sutey

Distr-1 
No. of

Copies

52 Pacific Northwest Laboratory

R. C. Adams

M. K. Altenhofen (10)

A. J. Boegel

J. L. Braitman

A. D. Chockie

L. L. Clark

C. A. Counts

J. W. Currie

P. M. Daling

R. L. Engel

J. F. Fletcher

R. M. Gale

R. E. Heineman
No. of

Copies

G. M. Holter

C. H. Imhoff

P. N. McDuffie

J. L. McElroy

R. W. McKee

G. W. MCNair

D. F. Newman

D. R. Payson

K. J. Schneider

G. H. Sewart

M. R. Shay (10)

R. I. Smith

M. B. Triplett

R. C. Walling

M. K. White

T. W. Wood

Publishing Coordination MH (2)

Technical Information (5) 